\title{
A Searchable Bibliography of Fallacies - 2016
}

\author{
Hans V. Hansen
}

Department of Philosophy

University of Windsor

Windsor, $O N$

CANADA N9B 3P4

hhansen@uwindsor.ca

\section{CAMERON Fioret}

Department of Philosophy

University of Guelph

Guelph, ON

CANADA NIG 2W1

fioretc@uoguelph.ca

This bibliography of literature on the fallacies is intended to be a resource for argumentation theorists. It incorporates and supplements the material in the bibliography in Hansen and Pinto's Fallacies: Classical and Contemporary Readings (1995), and now includes over 550 entries. The bibliography is here presented in electronic form which gives the researcher the advantage of being able to do a search by any word or phrase of interest. Moreover, all the entries have been classified under at least one of 45 categories indicated below. Using the code, entered as e.g., '[AM-E]', one can select all the entries that have been designated as being about the ambiguity fallacy, equivocation.

Literature about fallacies falls into two broad classes. It is either about fallacies in general (fallacy theory, or views about fallacies) or about particular fallacies (e.g., equivocation, appeal to pity, etc.). The former category includes, among others, considerations of the importance of fallacies, the basis of fallacies, the teaching of fallacies, etc. These general views about fallacies often come from a particular theoretical orientation about how fallacies are best understood; for example, some view fallacies as epistemological mistakes, some as mistakes in disagreement resolution, others as frustrations of rhetorical practice and communication. Accordingly, we have attempted to classify the en- 
tries about fallacies in general under one of several possible perspectives, but a given classifications is only an indication of the approach taken in the work, it does not imply that the entry is not relevant to other perspective on fallacies.

If fallacy-research is not about fallacies in general, it is about particular fallacies (e.g., equivocation, secundum quid, etc.), or particular kinds of fallacies (e.g., mathematical fallacies). We have decided on some 40 categories for classifying individual fallacies. There are also some other particular useful categories; for example, one indicating that the entry is devoted to a historical treatment of fallacies, the other an index of other bibliographies on fallacies.

This is a work in progress which will lend itself to correction in future versions by those who make use of it. We sincerely hope that readers will bring to our attention any of the mistakes in the present version. The kinds of mistakes we anticipate are: (i) mistakes in an entry (author(s), title, medium, date, pages, etc.); (ii) the inclusion of something that should not be in this bibliography; (iii) the failure to include something that should have been included in the bibliography; (iv) a mis-classification of an entry; and (v) a failure to add a useful classification code to an entry. (An entry can have more than one index code.)

For their help in developing the present version of the bibliography, we are very grateful to Andrew Aberdein, Maurice Finocchiaro, and Ralph H. Johnson.

\section{Coding key - Code to Subject}

\begin{tabular}{|l|l|}
\hline \multicolumn{2}{|c|}{ PERSPECTIVES ON FALLACIES } \\
\hline GF-N & Fallacies (theory) in general / no evident perspective \\
\hline GF-C & Fallacy taxonomies / classification \\
\hline GF-D & Fallacies (theory) - dialectical / dialogical perspective \\
\hline GF-E & Fallacies (theory) - alethic / logical /epistemic perspective \\
\hline GF-F & Fallacies (theory) -- formal (logic) perspective \\
\hline GF-T & Fallacies (theory) - pedagogical perspective / issues \\
\hline GF-R & Fallacies (theory) - rhetorical perspective \\
\hline GF-P & $\begin{array}{l}\text { Fallacies (theory) - sociological-gender-psychological } \\
\text { perspective }\end{array}$ \\
\hline GF-V & Fallacies (fallacy theory) - virtue/vice perspective \\
\hline
\end{tabular}


434 A Searchable Bibliography of Fallacies

\begin{tabular}{|l|l|}
\hline \multicolumn{2}{|c|}{ PARTICULAR, OR KINDS OF, FALLACIES } \\
\hline AA & $\begin{array}{l}\text { (Fallacious) Appeals to authority (includes fallacious } \\
\text { ad verecundiam) }\end{array}$ \\
\hline AB & Ad baculum \\
\hline AC & Ad consequentiam (fallacious appeal to consequences) \\
\hline AT & Accent \\
\hline AD & Accident \\
\hline AH-N & Ad hominem in general / no discrimination \\
\hline AH-A & Ad hominem abusive \\
\hline AH-C & Ad hominem circumstantial \\
\hline AH-L & Ad hominem Lockean \\
\hline AH-Q & Ad hominem tu quoque \\
\hline AI & Ad ignorantiam \\
\hline AM-A & Ambiguity - Amphiboly \\
\hline AM-E & Ambiguity - Equivocation \\
\hline CF & Collection. Includes papers/ chapters on fallacies \\
\hline BR & Base rate fallacy \\
\hline BT & Textbook with significant attention to fallacies \\
\hline BQ & Begging the question / Circular reasoning \\
\hline FM & Genetic fallacy \\
\hline FI & Intentional fallacy \\
\hline FA & Faulty analogy \\
\hline FB & Biased sample / Biased reasoning \\
\hline Fo & Causal fallacies (post hoc, false cause, common cause) \\
\hline Fo disjunction (dichotomy, alternatives) \\
\hline F
\end{tabular}

(C) Hans V. Hansen \& Cameron Fioret. Infomal Logic, Vol. 36, No. 4 (2016), pp. 432-472. 


\begin{tabular}{|l|l|}
\hline \multicolumn{2}{|c|}{ PARTICULAR, OR KINDS OF, FALLACIES } \\
\hline FK & Conjunction fallacy \\
\hline FM & Mathematical fallacy / fallacies \\
\hline FN & Naturalistic fallacy \\
\hline FQ & Many questions \\
\hline FR & Gambler's fallacy \\
\hline FX & Gender related fallacy / fallacies \\
\hline HG & Hasty generalization \\
\hline HIS & $\begin{array}{l}\text { Historical studies - modern work on historical expositions } \\
\text { of fallacies }\end{array}$ \\
\hline IE & Ignoratio elenchi / Strawman \\
\hline MIS & Ad misericordiam \\
\hline OB & Other fallacy bibliographies \\
\hline POP & Ad populum \\
\hline SB & Shifting the burden of proof illicitly \\
\hline ScF & Scope fallacy \\
\hline SQ & Secundum quid (fallacies dependent on qualifications) \\
\hline SS & Slippery slope \\
\hline SF & Statistical fallacy \\
\hline XX & Cannot classify \\
\hline YY & Should not be included in this bib \\
\hline
\end{tabular}

ALTA Proceedings: Proceedings of the NCA/AFA (National Communication Association/ American Forensic Association) Summer Conferences on Argumentation held at Alta, Utah, can be accessed through $<$ http://altaconference.org/proceedings.html>.

ALTA 8 (1993) R.E. McKerrow, Ed. Argument and the Postmodern Challenge. Annandale, VA: Speech Communication Association. 
ALTA 12 (2002) G.T. Goodnight, Ed. Arguing Communication \& Culture. Washington, DC: NCA.

ALTA 13 (2003) C.A. Willard, Ed. Critical Problems in Argumentation. Washington, DC: NCA.

ALTA 15 (2007) S. Jacobs, Ed. Concerning Argument. Washington DC: NCA.

ECA 1 (2016): Argumentation and Reasoned Action, Proceedings of the First European Conference on Argumentation, Lisbon 2015, Dima Mohammed and Marcin Lewiński, Eds. London: College Publications. (Bound in 2 volumes.)

ISSA Proceedings: The conference proceedings of the International Society for the Study of Argumentation (ISSA) can be accessed through the following works.

ISSA 1 (1986) Proceedings of the First International Conference on Argumentation F.H. van Eemeren, R. Grootendorst, J.A. Blair \& C.A. Willard, Eds. Dordrecht: Foris, 1987. (Bound in three volumes.)

ISSA 1 Argumentation: Across the Lines of Discipline.

ISSA 1A Argumentation: Perspectives and Approaches

ISSA 1B Argumentation: Analysis and Practices.

ISSA 2 (1990) Proceedings of the Second International Conference on Argumentation, F.H. van Eemeren, R. Grootendorst, J.A. Blair \& C.A. Willard, Eds. Amsterdam: SicSat, 1991. (Bound in two volumes.)

ISSA 3 (1994) Proceedings of the Third International Conference on Argumentation, F.H. van Eemeren, R. Grootendorst, J.A. Blair \& C.A. Willard, Eds. Amsterdam: SicSat, 1995. (Bound in four volumes)

ISSA 3A Perspectives and Approaches. (vol. 1)

ISSA 3B Analysis and Evaluation. (vol. 2)

ISSA 3C Reconstruction and Application (vol. 3)

SSA 3D Special Fields and Cases (vol. 4)

ISSA 4 (1998) Proceedings of the Fourth Conference of the International Society for the Study of Argumentation, F.H. van Eemeren, R. Grootendorst, J.A. Blair \& C.A. Willard, Eds. Amsterdam: SicSat, 1999.

ISSA 5 (2002) Proceedings of the Fifth Conference of the International Society for the Study of Argumentation. F.H. van Eemeren, J.A. Blair, C.A. Willard \& A.F. Snoeck Henkemans, Eds. Amsterdam: SicSat, 2003. 
ISSA 6 (2006) Proceedings of the Sixth Conference of the International Society for the Study of Argumentation. F.H. van Eemeren, J.A. Blair, C.A. Willard \& B. Garssen, Eds. Amsterdam: SicSat, 2007. (Bound in to volumes.)

ISSA 7 (2010) Proceedings of the Seventh Conference of the International Society for the Study of Argumentation. F.H. van Eemeren, B. Garssen, D. Godden \& G. Mitchell, Eds. Amsterdam: SicSat, 2007. [Compact Disc]

ISSA 8 (2014) Proceedings of the Eighth Conference of the International Society for the Study of Argumentation, B. Garssen, D. Godden, G. Mitchell \& A.F. Snoeck Henkemans, Eds. Amsterdam: SicSat, 2015. [Compact Disc]

OSSA Proceedings: The collected proceedings of the Ontario Society for the Study of Argumentation (OSSA) can be accessed through the http://scholar.uwindsor.ca/ossaarchive/.

OSSA 1 (1995) Argumentation and Education. Hans V. Hansen \& Christopher W. Tindale, Eds. Informal Logic 17:2.

OSSA 2 (1997) Argumentation and Rhetoric. Hans V. Hansen, Christopher W. Tindale \& Athena V. Colman, Eds. (St Catharines: OSSA, 1998)

OSSA 3 (1999) Argumentation at the Century's Turn. Christopher W. Tindale, Hans V. Hansen \& Elmar Sveda, Eds. (St. Catharines: OSSA, 2000)

OSSA 4 (2001) Argumentation and its Applications. Hans V. Hansen, Christopher W. Tindale, J. Anthony Blair, Ralph $\mathrm{H}$. Johnson \& Robert C. Pinto, Eds. (Windsor: OSSA, 2002)

OSSA 5 (2003) Informal Logic @ 25. J. Anthony Blair, Daniel Farr, Hans V. Hansen, Ralph H. Johnson \& Christopher W. Tindale, Eds. (Windsor: OSSA)

OSSA 6 (2005) The Uses of Argument. David Hitchcock \& Daniel Farr, Eds. (Hamilton: OSSA)

OSSA 7 (2007) Dissensus \& The Search for Common Ground. Hans V. Hansen, Christopher W. Tindale, J. Anthony Blair, Ralph H. Johnson \& David M. Godden, Eds. (Windsor: OSSA)

OSSA 8 (2009) Argument Cultures. Juho Ritola, Ed. (Windsor: OSSA)

OSSA 9 (2011) Argumentation: Cognition \& Community. Frank Zenker, Ed. (Windsor: OSSA)

OSSA 10 (2013) Virtues of Argumentation. Dima Mohammed \& Marcin Lewinski, Eds.(Windsor: OSSA)

OSSA 11 (2016) Argumentation, Objectivity and Bias. Patrick Bondy \& Laura Benacquista, Eds. (Windsor: OSSA) 


\section{A Searchable Bibliography of Fallacies, 2016 HaNS V. HANSEN \& CAMERON FioReT}

Abate, Charles J., 1979, "Fallacies and invalidity," Philosophy \& Rhetoric, 12: 262-6. [GF-N]

ABerdeIn, Andrew, 2007, "Fallacies in mathematics," Proc. of the British Society for Research into Learning Mathematics, 27: 1-6. [FM]

—, 2013, "Fallacy and argumentational vice," OSSA 10. [GF-V]

—, 2014, "In defence of virtue: The legitimacy of agent-based argument appraisal," Informal Logic 34: 77-93. [GF-V]

- , forthcoming, "The vices of argument," Topoi [GF-V]

Achourioti, THEOdORA, 2007, "Fallacies and contextdependence: Considering the strategic maneuvering approach," ISSA 6: 21-5. [GF-D]

AdLER, JONATHAN E., 1993, "Critique of an epistemic account of fallacies," Argumentation, 7: 263-72, [Criticism of Fogelin and Duggan 1987]. [GF-E]

, 1994, "Fallacies and alternative interpretations," Australasian J. of Philosophy, 72: 271-82. [GF-E]

, 1996, "Charity, interpretation, fallacy," Philosophy \& Rhetoric, 29: 329-43. [GF-E]

_, 1997, "If the base rate fallacy is a fallacy, does it matter how frequently it is committed?" Behavioral and Brain Sciences, 20: 774-5. [BR]

_, 2000, "Belief and negation," Informal Logic, 20: 207-22. [ScF]

_, 2007, "Conversation and dissemblance," in Hansen and Pinto $2007,201-12$. [FQ]

AIKIN, SCOTT, 2008, "Tu quoque arguments and the significance of hypocrisy," Informal Logic 28:155-69. [AH-Q]

_, 2016, "A (modest) defence of fallacy theory," OSSA 11. [GF-N]

Aikin, ScotT, and John CASEY, 2013, "Don't feed the trolls: straw men and iron men," OSSA 10. [IE]

_, forthcoming, "Straw men, iron men, and argumentative virtue," Topoi, [IE]

Anger, Beverley, and Catherine Hundleby, forthcoming, "Ad stuprum: The fallacy of appeal to sex," OSSA 11. [FX] 
BACHMAN, JAMES, 1995, “Appeal to authority," In Hansen and Pinto, 1995, 274-86. [AA]

BACK, ALLAN, 1987, "Philoponus on the fallacy of accident," Ancient Philosophy, 7: 131-46. [AD] [HIS

_. 2009, "Mistakes of reason: Practical reasoning and the fallacy of accident," Phronesis, 54: 101-35. [AD]

BAGWELL, GEOFFreY, 2011, "Does Plato argue fallaciously at Cratylus 385b-c?" Apeiron, 44: 13-21. [HIS]

BALL, ANDREW, forthcoming, "Are fallacies vices?" Topoi, $[\mathrm{GF}-\mathrm{V}]$

BARBEAU, E. J., 2000, "Mathematical fallacies, flaws, and flimflam," Mathematical Association of America, Washington D. C. [FM] [SF]

BAR-HiLlel, YeHoshuA, 1964, "More on the fallacy of composition," Mind, 73:125-6, [CM] [Reply to Rowe 1962].

BARKER, JOHN A., 1976, "The fallacy of begging the question," Dialogue, 15: 241-55. [BQ]

_, 1978, "The nature of question-begging arguments," Dialogue, 17: 490-8. [BQ]

BARTh, E. M., and J. L. MARTEns, 1977, "Argumentum ad hominem: from chaos to formal dialectic," Logique et Analyse, 20: 76-96. [AH-L]

BASU, DILIP K., 1986, “A question of begging," Informal Logic, 8: 19-26, [Reply to Woods and Walton 1982b]. [BQ]

_, 1994, "Begging the question, circularity and epistemic propriety," Argumentation, 8: 217-26. [BQ]

BATtERSBy, MARK, and SHARON BAILIN, 2011, "Fallacy identification in a dialectical approach to teaching critical thinking," OSSA 9. [GF-T] [GF-D]

BEHLING, RICHARD W., 1987, "On the naming of formal fallacies," International Logic Review, 18: 69-70. [Reply to Wertz 1985]. [FF]

Bencivenga, ERmanno, 1979, "On good and bad arguments," J. of Philosophical Logic, 8: 247-59. [Reply to Massey's 1975 papers] [GF-E]

VAN Bentham, Johan, Frans H. VAN EEMEREN, RoB Grootendorst and Frank VeltMAn (eds.), 1996, Logic and Argumentation, Amsterdam: Royal Netherlands Academy of Arts and Sciences. [CF]

Berman, Michael P, and Brian A. Lightbody, 2010, "The metaphoric fallacy to a deductive inference," Informal Logic, 30: 185-93. [FA] 
440 A Searchable Bibliography of Fallacies

BIRO, J. I., 1977, "Rescuing 'begging the question'," Metaphilosophy, 8: 257-71. [BQ]

_, 1984, "Knowability, believability and begging the question: a reply to Sanford," Metaphilosophy, 15: 239-47. [BQ]

_ 1987, "A sketch of an epistemic theory of fallacies," in ISSA 1B: 65-73. [GF-E],

BIRO, JoHN and HARVEY SIEGEL, 1992, "Normativity, argumentation and an epistemic theory of fallacies," in ISSA $1 B$ : 85103. [GF-E]

BLAIR, J. ANTHONY, 1995, "The place of teaching informal fallacies in teaching reasoning skills or critical thinking," in Hansen and Pinto 1995, 328-38. [GF-T]

Blair, J. ANTHONY, and RALPh H. Johnson, (eds.), 1980, Informal Logic: The FirstInternational Symposium, Inverness, Calif.: Edgepress,] (Selected papers from the First International Symposium on Informal Logic). [CF]

_, 1987, "The current state of informal logic and critical thinking," Informal Logic, 9: 147-51. [GF-E]

_, 1991, "Misconceptions of informal logic: A reply to McPeck," Teaching Philosophy, 14: 35-52, [GF-N] (Reply to McPeck 1991).

Boger, George, 2003, "Formal logic's contribution to the study of fallacies," ISSA 5: 133-7. [FF]

BOKMELDER, DMITRI, 2015, "Cogntiive biases and logical fallacies," ISSA 8: 147-53.

BONDY, PATRICK, 2016, "Bias in legitimate ad hominem arguments," OSSA 11. [AH-N] [FB]

Bonevac, Daniel, Josh Dever, and David Sosa, 2011, "The counterexample fallacy," Mind, 120: 1143-58. [SF]

BOONE, DANIEL N., 2002, "The cogent reasoning model of informal fallacies revisited," Informal Logic, 22: 93-111. [GFE]

Botting, DAVID, 2012, "Fallacies of accident," Argumentation, 26: 267-89. [AD]

_, 2012, "What is a sophistical refutation?" Argumentation, 26: 213-32. [GF-D]

_, 2014, "Without qualification: An inquiry into the secundum quid," Studies in Logic, Grammar and Rhetoric, 38: 161-70. [SQ]

Boudry, MaArten, Fabio Paglieri, and Massimo Pigliucci, 2015, "The fake, the flimsy, andthe fallacious: Demarcating arguments in real life," Argumentation, 29: 431-456. [GF-N] 
BRINTON, AlAN, 1985, "A rhetorical view of the ad hominem," Australasian J. of Philosophy, 63: 50-63. [AH-N]

_, 1992, "The ad baculum re-clothed," Informal Logic, 14:8592, [AB] (Disagrees with some conclusions in Wreen 1987b, 1988a, 1988b, 1989).

_, 1994, "A plea for argumentum ad misericordiam," Philosophia, 23: 25-44. [MIS]

_, 1995, "The ad hominem," in Hansen and Pinto 1995, 197212. [AH-N]

BROAD, C. D., 1950, "Some common fallacies in political thinking," Philosophy, 25: 99-113. [GF-N].

BROYLES, JAMES E., 1975, "The fallacies of composition and division," Philosophy \& Rhetoric, 8: 108-13. [CM] [DI]

BuENO, ANIBEL A., 1988, "Aristotle, the fallacy of accident, and the nature of predication: a historical inquiry," J. of the History of Philosophy, 26: 5-24. [AD] [HIS]

Bunch, BRYAN, 1997, Mathematical Fallacies and Paradoxes, New York: Dover Publications. [FM]

BURKe, MichaEL, 1994, "Denying the antecedent," Informal Logic, 16: 23-30. [FF]

Capaldi, Nicholas, 1973, The Art of Deception, Buffalo: Prometheus Books. [BT]

CARroll, NoËL, 1997, "The intentional fallacy: defending myself," J. of Aesthetics and Art Criticism, 55.3: 305-9. [FI]

CARroll, RoBert, 2013, The Critical Thinker's Dictionary: Biases, Fallacies, and Illusions and What You Can Do About Them, Amazon: Kindle Ebook. [BT]

Chatham, Christopher Hughes, 2013, "The consistency fallacy and failures of theory embellishment," Frontiers in Psychology, 4: 965. [GF-P]

Ciurria, Michelle, and Khameiel Altamimi, 2014, "Argumentum ad vericundiam: new gender based criteria for appeals to authority," Argumentation, 28: 437-52. [AA] [FX]

COHEN, DANIEL H., 2003, "Logical fallacies, dialectical transgressions, rhetorical sins, and other failures of rationality in argumentation," ISSA 5: 201-6. [GF-N]

CoHen, L. JonAthan, 1979, "On the psychology of prediction: whose is the fallacy?" Cognition, 7: 385-407. [GF-P]

_, 1980, "Whose is the fallacy: a rejoinder to Daniel Kahneman and Amos Tversky," Cognition, 8: 89-92. [GF-P]

_, 1982, “Are people programmed to commit fallacies?" J.for the Theory of Social Behaviour, 12: 251-74. [GF-P] 
Cole, Richard, 1965, "A note on informal fallacies," Mind, 74: 432-3. [GF-E]

COLEMAN, EDwIN, 1995, "There is no fallacy of arguing from authority," Informal Logic, 17: 365-383. [AA]

_, 2007, "Mediated Fallacies," ISSA 6: 265-9. (Some fallacies are dependent on the medium in which they occur.) $[\mathrm{XX}]$

Collins, JoHn M., 2011, “Agent-relative fallacies," ISSA 7: 281-8. [XX]

COlwell, GARY, 1989, "God, the Bible and circularity," Informal Logic, 11: 61-73. [BQ]

Copi, Irving M., 1953, Introduction to Logic, New York: Macmillan. Subsequent editions $2^{\text {nd }}$ to $7^{\text {th }}: 1961,1968,1972$, $1978,1982,1986$; with CARL COHEN, $8^{\text {th }}$ to $10^{\text {th }}, 1990,1994$, 1998; with third author, KENNETH MCMAHON, $11^{\text {th }}$ to $14^{\text {th }}$ : 2002, 2005, 2009, 2011, Pearson Publications. [BT]

Cowan, JosePh L., 1969, “The gambler's fallacy,” Philosophy and Phenomenological Research, 30: 238-51. [FR]

Crouch, Margaret A., 1991, "Feminist philosophy and the genetic fallacy," Hypatia, 6: 104-17. [FG]

_, 1993, "A 'limited' defense of the genetic fallacy," Metaphilosophy, 24: 227-40. [FG]

Cummings, Louise, 2000, "Mind and body, form and content: how not to do petitio principia analysis," Philosophical Papers, 29: 73-105. [BQ]

_, 2000, "Petitio principii: The case for non-fallaciousness," Informal Logic, 20: 1-18. [BQ]

_, 2002, "Evaluating fallacies: Putnam's model-theoretic legacy," Philosophica, 69: 61-84. [GF-E]

_, 2002, "Hilary Putnam's dialectical thinking: an application to fallacy theory," Argumentation, 16: 197-229. [GF-E]

_, 2002, "Reasoning under uncertainty: the role of two informal fallacies in an emerging scientific inquiry," Informal Logic, 22: 113-36. [AI] [FA]

, 2003, "Formal dialectic in fallacy inquiry: An unintelligible circumscription of argumentative rationality?" Argumentation, 17: 161-83. [GF-D]

_, 2004, "Analogical reasoning as a tool of epidemiological investigation," Argumentation, 8: 427-44. [FA]

_, 2004, "Argument as cognition: A Putnamian criticism of Dale Hample's cognitive conception of argument," Argumentation, 18: 331-48. [ GF-E] 
, 2004, "Rejecting the urge to theorise in fallacy inquiry," $A r$ gumentation, 18: 61-94. [GFN]

_, 2005, "Giving science a bad name: Politically and commercially motivated fallacies in BSE inquiry," Argumentation, 19: 123-43. [AA] [FA]

_, 2009, "Emerging infectious diseases: Coping with uncertainty," Argumentation, 23: 171-88. [AI] [FA]

_, 2010, Rethinking the BSE Crisis: A Study of Scientific Reasoning under Uncertainty, Dordrecht: Springer. [AH-N] [AI] [AA] [BQ] [FA] [IE]

, 2011, "Considering risk assessment up close: The case of bovine spongiform encephalopathy," Health, Risk \& Society, 13: 255-275. [AI] [FA]

, 2012, "The contribution of informal logic to public health," Perspectives in Public Health, 132: 66-7. [AI] [GF-N]

, 2012, "The public health scientist as informal logician," International J. of Public Health, 57: 649-50. [AI] [FA]

_, 2012, "Scaring the public: Fear appeal arguments in public health reasoning," Informal Logic, 32: 25-50. [AB]

_, 2013, "Circular reasoning in public health," Cogency, 5: 3576. [BQ]

_, 2013, "Public health reasoning: Much more than deduction," Archives of Public Health,71: 25. [AI] [AA] [BQ] [FA]

_, 2014, "Analogical reasoning in public health," J. of Argumentation in Context, 3: 169-97. [FA]

_, 2014, "Circles and analogies in public health reasoning," Inquiry, 29: 35-59. [BQ] [FA]

_, 2014, "Coping with uncertainty in public health: The use of heuristics," Public Health, 128: 391-4. [AI] [AA] [BQ] [FA]

, 2014, "Informal fallacies as cognitive heuristics in public health reasoning," Informal Logic, 34: 1-37. [AI] [AA]

, 2014, "Public health reasoning: A logical view of trust," Cogency, 6: 33-62. [AA]

_, 2014, "The 'trust' heuristic: Arguments from authority in public health," Health Communication, 29: 1043-56. [AA]

_, 2015, Reasoning and Public Health: New Ways of Coping with Uncertainty, Dordrecht: Springer. [AI] [AA] [BQ] [FA]

, 2015, "The use of 'no evidence' statements in public health," Informal Logic, 35: 32-65. [AI] 
Cusick, Carolyn, and Mark Peter, 2015, "The last straw fallacy: Another causal fallacy and its harmful effects," Argumentation, 29: 457-74. [CF]

DAMER, T.E., 2009, Attacking faulty reasoning: a practical guide to fallacy-free arguments, $6^{\text {th }}$ ed., Belmont, California: Wadsworth. [BT]

De WiJze, Stephen, 2003, "Complexity, relevance and character: problems with teaching the ad hominem fallacy," Educational Philosophy and Theory, 35, 1:31-56. [AH-N]

Dickie, GeOrge, and W. KENT Wilson, 1995, "The intentional fallacy: defending Beardsley," J. of Aesthetics and Art Criticism, 53: 233-50. [FI]

DREHE, IOVAN, 2016, "Fallacy as vice and/or incontinence in decision making," ECA 1 vol 2: 407-16. [GF-V]

Dodd, Julian, and SuZANne Stern-Gillet, 1995, "The is/ought gap, the fact/value distinction and the naturalistic fallacy," Dialogue, 34: 727-46. [FN]

Dowden, BRADLEY, 2008, "Fallacies," The Internet Encyclopedia of Philosophy, <http://www.iep.utm.edu/fallacy/>. [GF$\mathrm{N}]$

Dufour, Michel, 2013, "Commentary on: Maurice Finocchiaro's 'The fallacy of composition and meta-argumentation'," OSSA 10. [CM]

, 2016, "What difference between fallacy and sophism," $O S$ $S A$ 11. [GF-N] [GF-C]

van Eemeren, Frans H., 2001, "Fallacies," In F. H. van Eemeren (ed.) Crucial Concepts in Argumentation Theory, Amsterdam: Amsterdam University Press, 135-64. [GF-D]

_, 2010, Strategic Maneuvering in Argumentative Discourse. Extending the Pragma-Dialectical Theory of Argumentation, Philadelphia: John Benjamins. (Chs. 7 and 9 especially.) [GF-D]

_,2012, "The pragma-dialectical theory under discussion," Argumentation, 26: 439-57. [GF-D]

, 2013, "Fallacies as derailments of argumentative discourse: Acceptance based on understanding and critical assessment," J. of Pragmatics, 59: 141-152. [GF-D]

VAn Eemeren, Frans H., and Bart Garssen, 2010, "Linguistic criteria for judging composition and division fallacies," in A. Capone (ed.), Perspectives on Language Use and Pragmatics. A Volume in Memory of Sorin Stati, Munich: Lincom Europa, 35-50. [CM] [DI] 
VAn Eemeren, Frans H., Bart Garssen, and Bert Meuffels, 2002, "The unreasonableness of the ad baculum fallacy," in ALTA 12: 343-50. [AB]

_, 2015, "The disguised ad baculum fallacy empirically investigated - strategic maneuvering with threats," ISSA 8: 13961407. [AB]

van Eemeren, Frans H., Bart Garssen, Erik C.W. Krabbe, A. Francisca Snoeck Henkemans, Bart VerheiJ, and JeAn H. WAGEMAns, 2014, "Classified Bibliography," in (by the same authors) Handbook of Argumentation Theory, Dordrecht: Springer. (See especially the bibliographies connected to chs. $1-3,6$.) [OB]

_, 2005, "This can't be true, that would be terrible: Ordinary arguers judgments about ad consequentiam fallacies," in $A L$ TA 13: 669-75. [AC]

_, 2007, "Convergent operations in empirical ad hominem research," in ISSA 6: 367-73. [AH-N]

_, 2008, "Reasonableness in confrontation. Empirical evidence concerning the assessmentof ad hominem fallacies," in F.H. van Eemeren and Bart Garssen (eds.), Controversy and Confrontation. Relating Controversy Analysis with Argumentation Theory, Amsterdam: John Benjamins, 181-95. [AH-N]

_, 2009, Fallacies and Judgments of Reasonableness. Empirical Research Concerning the Pragma-Dialectical Discussion Rules, Dordrecht: Springer. [GF-D]

, 2012, "The disguised abusive ad hominem empirically investigated: Strategic maneuvering with direct personal attacks," Thinking \& Reasoning 18: 344-64. [AH-N]

VAN Eemeren, Frans H. and RoB Grootendorst, 1984, Speech Acts in Argumentative Discussions, Dordrecht: Foris. [chap. 8 considers a code for rational discussants and itsrelation to the fallacies]. [GF-D]

, 1987, "Fallacies in pragma-dialectical perspective," Argumentation, 1: 283-301. [GF-D]

, 1989, "A transition stage in the theory of fallacies," J. of Pragmatics, 13: 99-109. [GF-D]

_, 1992a, Argumentation, Communication, and Fallacies. Hillsdale: Erlbaum. (Chapters 819 especially.) [GF-D]

, 1992b, "Relevance reviewed: the case of argumentum ad hominem," Argumentation, 6: 141-59. [AH-L]

, 1993, "Fallacies in a pragma-dialectical perspective," in $A L-$ TA 8: 179-87. [GF-D] [OB] 
, 1993, "The history of the argumentum ad hominem since the seventeenth century," In Krabbe et al., 1993: 49-68. [AH-N] [HIS]

_, 1995, “Argumentum ad hominem: a pragma-dialectical case in point," Hansen and Pinto, Fallacies, 1995, 223-28. [AH$\mathrm{N}]$

, 1995, "The pragma-dialectical approach to fallacies," In Hansen and Pinto 1995, 130-44. [GF-D]

_, 2004, A Systematic Theory of Argumentation: The PragmaDialectical Approach, Cambridge, UK: Cambridge University Press. (Especially, Ch. 7) [GF-D]

van Eemeren, Frans H., Rob Grootendorst, Bert MeufFELS, and MARIEL VERBURG, 1999, "The (un)reasonableness of ad hominem fallacies," in ISSA 4: 172-7. [AH-N]

VAn Eemeren, Frans H. and Peter Houtlosser, 2003, "Fallacies as derailments of strategic maneuvering: The argumentum ad verecundiam, a case in point," ISSA 5: 289-92. [GF

D]

_, 2003, "More about fallacies as derailments of strategic maneuvering: The case of tu quoque," in OSSA 5. [AH-Q]

_, 2007, "The contextuality of fallacies," Informal Logic, 27: 59-68. [GF-D]

, 2007, "Countering fallacious moves," Argumentation, 21: 243-52. [GF-D]

, 2008, "Reconnecting dialectic and rhetoric: Fallacies as derailments of strategic manoeuvring in argumentative discourse," Anthropology \& Philosophy, an International Multidisciplinary J., 8: 49-67. [GF-D]

_ , 2009, "How should one respond to fallacious moves?" Argumentation and Advocacy 45: 198-206. [GF-D]

van Eemeren, Frans H., Bert Meuffels and Mariel VerBURG, 2000, "The (un)reasonableness of the argumentum ad hominem," Language and Social Psychology, 19: 416-35. [AH-N]

Engel, S. Morris, 1961, "Hobbes's 'table of absurdity'," Philosophical Review, 60: 533-43. [GF-N]

, 1980, Analyzing Informal Fallacies, Englewood Cliffs: Prentice-Hall. [BT]

_, 1986, “Explaining equivocation,” Metaphilosophy, 17: 19299. [AM-E]

, 1986, "Fallacy, wit, and madness," Philosophy \& Rhetoric, 19: 224-41. [GF-N] 
, 1986, "Wittgenstein's theory of fallacy," Informal Logic, 8: 67-80. [MIS] [GF-N]

_, 1989, "The many faces of amphiboly," Metaphilosophy, 20: 347-55. [MIS]

_, 1991, "Understanding, finally, what it is to "beg the question," Metaphilosophy, 22: 251-64. [BQ]

_, 1994, With Good Reason: An Introduction to Informal Fallacies, 5th ed., New York: St. Martin's, [1 ${ }^{\text {st }}$ ed. 1976]. [BT]

FAcione, Peter, 1987, "Teaching about fallacies," Teaching Philosophy, 10: 211-7. [GF-T]

FAIR, FRANK, 1973, “The fallacy of many questions: or how to stop beating your wife," Southwestern J. of Philosophy 4: 8992. [FQ]

Fearnside, W. Ward, and William B. Holther, 1959, Fallacy: The Counterfeit of Argument, Englewood Cliffs: PrenticeHall. [BT]

FETERIS, E.T., 1991, "Fallacies and legal argumentation," ISSA 2: 768-75. [GF-D]

FEUER, LEWIS S., 1983, "The genetic fallacy re-examined," in Sidney Hook: Philosopher of Democracy and Humanism, Paul Kurtz (ed.), 227-46. Buffalo: Prometheus Books. [FG]

FinOCCHIARO, MAURICE, 1974, "The concept of ad hominem argument in Galileo and Locke," Philosophical Forum, 5: 394-404. (Reprinted in Finocchiaro 2005, 329-39.) [AH-L]

,1981, "Fallacies and the evaluation of reasoning," American Philosophical Q., 18: 13-22. (Reprinted in Finocchiaro 2005, 109-27.) [GF-E]

, 1987, "Six types of fallaciousness: toward a realistic theory of logical criticism," Argumentation, 1: 263-82. (Reprinted in Finoccharo 2005, 128-47.) [GF-E]

, 1995, "Six types of fallaciousness: toward a realistic theory of logical criticism," in Hansen and Pinto 1995, 107-19. [GFE]

_, 2001, "Valid ad hominem arguments in philosophy: Johnstone's metaphilosophical informal logic," Informal Logic, 21: 11-24. (Reprinted in Finocchiaro 2005, 292-326.) [AH-N] , 2005 Arguments about Arguments: Systematic, Critical and Historical Essays in Logical Theory, Cambridge: Cambridge University Press.

, 2013, "Debts, oligarchies, and holisms: deconstructing the fallacy of composition," Informal Logic, 33: 143-74. [CM] 
_, 2013, "The fallacy of composition and meta-argumentation," OSSA 10. [CM]

_, 2014, Essay-review of J. Woods's Errors of Reasoning: Naturalizing the Logic of Inference, Argumentation, 28: 2319. [GF-E]

_, 2015, "The fallacy of composition: guiding concepts, historical cases, and research problems," J. of Applied Logic, 13: 24-43. [CM]

_, 2015, "Ubiquity, ambiguity, and metarationality: Searching for the fallacy ofcomposition," in Reflections on Theoretical Issues in Argumentation Theory, Frans H.van Eeemeren and Bart Garssen (eds.), Dordrecht: Springer, 131-41. Also in $I S$ $S A$ 8: 426-34. [CM]

_.,2016, "Economic reasoning and fallacy of composition: Pursuing a Woods Walton thesis," OSSA 11. [GF-E] [GF-C]

FISCHER, DAVID H., 1978, Historians' Fallacies: Toward a Logic of Historical Thought, New York: Harper and Row. [XX]

FLORIDI, LUCIANO, 2009, "Logical fallacies as informational shortcuts," Synthese, 167: 317-25. [GF-E]

Fogelin, Robert J., and Timothy J. Duggan, 1987, "Fallacies," Argumentation, 1: 255-62. [GF-N]

FreEman, JAMES B., 1995, "The appeal to popularity and presumption by common knowledge," In Hansen and Pinto 1995, 265-73. [AM-A]

Gelber, Hester Goodenough, 1987, "The fallacy of accident and the dictum de omni," Vivarium, 25: 110-45. [AD]

George, Rolf, 1983, “A postscript on fallacies," J. of Philosophical Logic, 12: 319-25. [GF-N]

Gerber, D., 1974, "On argumentum ad hominem," The Personalist, 55: 23-9. [AH-N]

, 1977, "Reply to Woods and Walton's 'Ad hominem, contra Gerber." The Personalist, 58: 145-6. [Reply to Woods and Walton 1977b] [AH-N]

Gert, Joshua, 2002, "Avoiding the conditional fallacy," Philosophical Q., 52: 88-95. [FF]

GILARDONI, ANDREA, 2009, "Using the 'protocols': fallacies and rhetorical strategies," OSSA 8. [GF-R]

GiLbert, Michael A., 2002, "Effing the ineffable: The logocentric fallacy in argumentation," Argumentation, 16: 21-32. [GF-E] 
Girard, PATrick, and LuCA Moretti, 2014, "Antirealism and the conditional fallacy: The semantic approach," J. of Philosophical Logic, 43: 761-83. [FF]

GodDEn, DAvid M., 2004, "Denying the antecedent as a legitimate argumentative strategy: a dialectical model." Informal Logic, 24: 219-43. [FF]

GooD, I. J., 1959, "A classification of fallacious arguments and interpretations," Methodos, 11: 147-59. [GF-C]

GoODWIN, DAVID, 1992, "The dialectic of second-order distinctions: The structure of arguments about fallacies," Informal Logic, 14: 11-22. [GF-D]

_, 2010, "The 'passes-for' fallacy and the future of critical thinking," Argumentation: 24: 363-74. [HG]

Gorham, GeOFFrey, 1996, "Does scientific reasoning beg the question?," Informal Logic, 18: 225-31. [BQ]

Goudge, T. A., 1961, “The genetic fallacy,” Synthese, 13: 41-8. [FG]

Gough, JAmes E., and MANO DANiEL, 2009, "The fallacy of composition," OSSA 8. [CM]

GOVIER, TRUDY, 1982, "What's wrong with slippery slope arguments?" Canadian J. of Philosophy, 12: 303-16. [SS]

__, 1983, "Ad hominem: Revising the textbooks," Teaching Philosophy, 6: 13-24. [AH-N]

_ , 1983, "Who says there are no fallacies?" Informal Logic, 5: 2-10. [GF-E]

_, 1987, Problems in Argument Analysis and Evaluation, Dordrecht: Foris. [GF-E]

_, 1992, A Practical Study of Argument, $3^{\text {rd }}$ ed. Belmont: Wadsworth, [1st ed. 1985]. [BT]

_., 1995, "Reply to Massey," In Hansen and Pinto 1995, 17280. [GF-E]

_, 2007, "Duets, cartoons, and tragedies: struggles with the fallacy of composition," ISSA 6: 505-11. [CM]

_, 2007, "Considering questions about questions," in Hansen and Pinto 2007, 171-86. [FQ]

GroARKE, LEO, 1991, "Critical study of Woods and Walton's fallacies: Selected Papers, 1972-1982, Informal Logic, 13: 99-112. [GF-E]

Grootendorst, RoB, 1987, "Some fallacies about fallacies," In van Eemeren, Grootendorst, et al., 1987a, 331-42. [GF-D] 
Grootendorst, RoB and Frans H. van Eemeren, 1993, "Perelman and the fallacies," In G.Haarscher (ed.), Chaim Perelman et la Pensée Contemporaine, Brussels: Bruylant, 26578. [GF-D]

HAHN, Ulrike, and Mike OAKSFORD, 2006, "A Bayesian approach to informal logical fallacies," Synthese, 152: 207-36. [GF-E]

Hamblin, Charles L., 1970, Fallacies. London: Methuen, [Available from Newport News:Vale Press]. [GF-N]

HAMPLE, DALE, 1982, "Dual coding, reasoning and fallacies," $J$. of the American Forensic Association, 19: 59-78. [GF-N]

Hample, Dale, A. K. Jones and J.M. Averbeck, 2009, "The rational engine: How do arguers deal spontaneously with fallacies?" in ALTA 2009 [GF-N]

Hample, Dale, Anita Sells and Ana Laura Inclán VelázQUEZ, 2009, "The effects of topic, type and personalization of conflict on assessments of fallacies," Communication Reports, 22: 74-88. [GF-R]

HANSEN, HANS V., 1995, "Select bibliography of recent work on the fallacies," in Hansen and Pinto 1995, 339-48. [OB]

_, 2000, "Logic and misery: Walton's Appeal to Pity," Informal Logic, 20: 169-84. [MIS]

_, 2002, "The straw thing of fallacy theory: the standard definition of "fallacy'," Argumentation, 16: 133-55. [GF-E]

_, 2015, "Fallacies," The Stanford Encyclopedia of Philosophy, <http://plato.stanford.edu/archives/sum2015/entries/falla cies/ $>$. [GF-N]

Hansen, Hans V., and Robert C. Pinto (eds.), 1995, Fallacies: Classical and Contemporary Readings, University Park: Pennsylvania State University Press. [GF-N]

_, 2007, Reason Reclaimed: Essays in Honor of J. Anthony Blair and Ralph H. Johnson. Newport News: Vale Press. $[\mathrm{CF}]$

HANSON, NORWOOD R., 1967, "The genetic fallacy revisited," American Philosophical Q. 4: 101-13. [FG]

HARMAN, OREN, 2012, "Is the naturalistic fallacy dead (and if so, ought it be?)." J. of theHistory of Biology, 45: 557-72. [FN]

Harre, Rom, 2012, "Behind the mereological fallacy." Philosophy, 87: 329-52. [CM] 
HARRISON, JONATHAN, 1995, "Ethical egoism, utilitarianism and the fallacy of pragmatic inconsistency," Argumentation, 9: 595-609. [AH-Q]

HASPER, P.S., 2013, “The ingredients of Aristotle's theory of fallacy," Argumentation, 27: 31-47. [GF-D] [HIS]

Hinman, LAWrence, 1982, "The case for ad hominem arguments," Australasian J. of Philosophy, 60: 338-45. [AH-N]

HINTIKKA, JAAKKO, 1987, "The fallacy of fallacies," Argumentation, 1: 211-38. [BQ] [FQ] [GFD]

HitchCOCK, DAVID, 1992, "Relevance," Argumentation, 6: 25170, [Includes section devoted to the relevance of "ad" appeals]. [GF-N]

, 1995, “Did Jesus commit a fallacy?” Informal Logic, 17: 297-302. [FF]

, 1995, "Do the fallacies have a place in the teaching of reasoning skills or critical thinking?" In Hansen and Pinto 1995, 319-27. [GF-N]

_, 2007, "Is there an argumentum ad hominem fallacy?" in Hansen and Pinto 2007, 187-99. [AH-N]

HOFFMAN, ROBERT, 1971, "On begging the questions at any time," Analysis, 32: 51. [BQ]

HoHman, HANS, 1991, "Fallacies and legal argumentation," in Van Eemeren, Grootendorst et al., 1991b, 776-81. [XX]

Hon, GIORA, 1991, “A critical note on J. S. Mill's classification of fallacies, British J. for the Philosophy of Science, 42: 2638. [GF-C] [HIS]

Hooke, A. E., 1991, "Tortuous logic and tortured bodies. Why is the ad baculum a fallacy?" In ISSA 2: 391-6. [AB]

HundLEBy, CATHERINE, 2009, "Fallacy forward: situating fallacy theory," OSSA 8. [GF-P]

_, 2010, "The authority of the fallacies approach to argument evaluation," Informal Logic, 30: 279-308. [FX]

_, 2011, "Androcentrism as a fallacy of argumentation," OSSA 9. $[\mathrm{FX}]$

_, 2012, "Ad baculum and freedom of speech," RAIL Blog (31 Jul. 2012), <http://railct.com/2012/07/31/ad-baculum-andfreedom-of-speech/> [AB]

IKUENOBE, POLYCARP, 2002, In search of criteria for 'fallacies' and 'begging the question,"' Argumentation, 16: 421-41. [BQ]

_, 2004, "On the theoretical unification and nature of fallacies," Argumentation, 18: 189-211. [GF-N] 
ISEMINGER, GARY, 1989, "The asymmetry thesis," The Monist, 72: 25-59, [Discussion of Massey 1975a, 1975b, 1981]. [GFE]

JACKSON, SALLY, 1995, "Fallacies and heuristics," in ISSA 3B: 257-69. Also in van Bentham et al. (eds.) 1996: 101-14 [GF$\mathrm{N}]$

JACKSON, FrANK, 1984, "Petitio and the purpose of arguing," Pacific Philosophical Q., 65: 26-36. [BQ]

JACQUETTE, DALE, 1989, "The hidden logic of slippery slope arguments," Philosophy and Rhetoric, 22: 59-70. [SS]

, 1994, "Many questions begs the question (but questions do not beg the question)," Argumentation, 8: 283-9. [FQ]

, 2007, "Deductivism and the informal fallacies," ISSA 6: 687-92. [GF-E]

JANACK, MARIANNE, and JOHN ADAMS, 1999, "Feminist epistemologies, rhetorical traditions and the ad hominem," The Changing Tradition: Women in the History of Rhetoric, in Christine Mason Sutherland and Rebecca Sutcliffe (eds.), Calgary: U. of Calgary, 213-24. [FX] [AH-N]

Jarvstad, Andreas, and Ulrike Hahn, 2011, "Source reliability and the conjunction fallacy," Cognitive Science, 35: 682-711. [FK]

JASON, GARY, 1984, "Is there a case for ad hominem?" Australasian J. of Philosophy, 62: 182-5. [AH-N]

, 1986, "Are fallacies common? A look at two debates," Informal Logic, 8: 81-92. [AH-N] [FC] [AM-A]

_, 1987, "The nature of the argumentum ad baculum," Philosophia, 17: 491-9. [AB]

, 1988, "Hedging as a fallacy of language," Informal Logic, 10: 169-75. [XX]

_, 1989, "Fallacies are common,” Informal Logic, 11: 101-06. [GF-N]

_, 2011, "Does virtue epistemology provide a better account of the ad hominem argument? A reply to Christopher Johnson (2009)," Philosophy, 8: 695-719. [AH-V]

JefFerson, AnNeli, 2014, "Slippery-slope arguments," Philosophy Compass, 9: 672-80. [SS]

JOHNSON, CHRISTOPHER, 2009, "Reconsidering the ad hominem," Philosophy: 84: 251-66. [AH-V]

Johnson, Oliver A., 1967-8, "Begging the question," Dialogue, 6: 135-50. [BQ] 
JOHNSON, RALPH H., 1987, "The blaze of her splendors: suggestions about revitalizing fallacy theory," Argumentation 1: 239-53. Also in Hansen and Pinto 1995, 97-106. [GF-N]

_ , 1989, "Massey on fallacy and informal logic: a reply," Synthese, 80: 407-26, (Reply to Massey 1981]). Also in Johnson 1996, 181-97. [GF-N]

, 1990, "Hamblin on the standard treatment," Philosophy \& Rhetoric, 23: 153-67. Also in Johnson 1996, 153-66. [GF-N]

, 1991, "In response to Walton," Philosophy \& Rhetoric, 24: 362-6, (Reply to Walton 1991d on Hamblin on the standard treatment.) [GF-N]

, 1996, The Rise of Informal Logic, Newport News: Vale Press. [GF-N]

_, 2000, "Informal logic: an overview," Informal Logic, 20: 93-107. [GF-E]

Johnson, RALPh H., and J. ANTHONy Blair, 1985, "Informal logic: The past five years, 1978-83," American Philosophical Q., 22: 181-96. [GF-N]

_, 1993, Logical Self-Defense, 3rd ed., Toronto: McGraw-Hill Ryerson, (1st ed. 1977. New York: International Debate Education Association, 2006.) [BT]

, 1994, New Essays in Informal Logic, Windsor: Informal Logic. [CF]

JÖnSSON, Martin L. and Elias Assarsson, 2013, "Shogenji's measure of justification and the inverse conjunction fallacy," Synthese, 190: 3075-85. [FK]

KaCPRZAK, Magdelena, and Olena Yaskorska, 2014, "Dialogue protocols for formal fallacies," Argumentation 28: 34969. $[\mathrm{FF}]$

KAHANE, HowARD, 1980, "The nature and classification of fallacies," in Blair and Johnson, 1980, 31-9. [GF-E] [GF-C]

KAHANE, HowARD and NANCY CAVENDER 2015, Logic and Contemporary Rhetoric, The Use of Reasoning in Everyday Life, $12^{\text {th }}$ ed., Boston: Engage Learning. $1^{\text {st }}$ edition (1971) through the $7^{\text {th }}$ by KAHANE alone, Belmont: Wadsworth. [BT]

KAPTEIN, HENDRIK, 2003, “Tu quoque? Fallacy and vindication in appeal to other people's 'wrongs'," ISSA 5: 593-7. [AH-Q]

KARY, DAVID, 2013, “Commentary on: Juhani Rudanko's 'Identifying a new type of fallacy in political discourse'," OSSA 10. $[\mathrm{XX}]$ 
KeKES, John, 1995, "Pluralism, scientific knowledge, and the fallacy of overriding values," Argumentation, 9: 577-94. $[\mathrm{XX}]$

KIEnPoInTner, MANFRED, 2011, "When figurative analogies fail: Fallacious uses of arguments from analogy," ISSA 7: 927-38. [FA]

KIMBALl, RoBert H., "What's wrong with argumentum ad baculum? Reasons, threats, and logical norms," Argumentation, 20: 89-100. [AB]

KIRWIN, CHRISTOPHER, 1979, "Aristotle and the so-called fallacy of equivocation," Philosophical Q., 29: 35-46. [AM-E] [HIS]

KIŠIČEK, GABRIJELA, and DAVOR STANKOVIĆ, 2011, “Analysis of fallacies in Croatian parliamentary debate," ISSA 7: 93948. [GF-N]

Kleiman, Lowell, 1970, "Pashman on Freud and the genetic fallacy," Southern J. of Philosophy, 8: 63-5, [Reply to Pashman, 1970]. [FG]

Klosko, George, 1983, "Criteria of fallacy and sophistry for use in the analysis of Platonic dialogues," Classical Q., n.s., 33: 363-74. [GF-N] [HIS]

, 1987, "Plato and the morality of fallacy," American J. of Philology, 108: 612-26. [GF-N] [HIS]

Korb, KEvin, 2004, "Bayesian informal logic and fallacy," Informal Logic, 24: 41-70. [AH-N] [AM-A] [FF] [SF] [PP]

Kotzee, Ben, 2010, "Poisoning the well and epistemic privilege," Argumentation, 24: 265-81. [AH-N]

KrabBe, ERIK C. W., 1992, "So what? Profiles for relevance criticism in persuasion dialogues," Argumentation, 6: 271-83, [Includes discussion of some of the fallacies of relevance.] [IE]

, 1993, Book review of John Woods and Douglas N. Walton, Fallacies: Selected Papers 1972-1982, Dordrecht: Foris Argumentation 6:475-9. [GF-N]

, 1993, "Reasonable argument and fallacies in the KokStekelenburg debate," In Krabbe et al. (eds.) 1993, 81-101. [GF-N]

_, 1995, “Appeal to ignorance," in Hansen and Pinto 1995, 251-64. [AI] 
, 1996, “Can we ever pin one down to a formal fallacy?" in Johan van Benthem, FransH. van Eemeren, Rob Grootendorst, and Frank Veltman (eds.), Logic and Argumentation, Amsterdam: North-Holland, 129-141. [FF]

, 1998, "Who is afraid of figure of speech?" Argumentation, 12: 281-94. [On the fallacy of figure of speech/form of expression]. [XX]

_, 2002, "Profiles of dialogue as a dialectical tool," in F. H. van Eemeren (ed.), Advances in Pragma-Dialectics, Amsterdam: Sic-Sat, 153-67. [Contains discussion of fallacy criticism, especially the "fallacy of equivocation"]. [AM-E] [GFD]

_, 2007, "Nothing but objections!" in Hansen and Pinto 2007, 51-63. [Discusses the "fallacy of objection" and the "converse fallacy of objection"]. [GF-D]

, 2007, "Commentary on Trudy Govier: 'Two is a small number: False dichotomies revisited,"' OSSA 7. [FD]

_, 2009, Review of Tindale 2007b, Argumentation, 23: 127131. [GF]

, 2012, “Aristotle's 'On Sophistical Refutation,"” Topoi, 31: 243-8. [GF-D] [HIS]

KrabBe, ERIK C. W., and Douglas N. Walton, 1994, "It's all very well for you to talk! Situationally disqualifying ad hominem attacks," Informal Logic, 15: 79-91. [AH-N]

KrabBe, ERIK C. W., and JAN Albert VAn LAAR, 2007, “About old and new dialectic: dialogues, fallacies, and strategies." Informal Logic, 27: 27-58. [GF-D]

KrabBe, Erik C.W., R. J. Dalitz, and P. A. Smit, (eds.), 1993, Empirical Logic and Public Debate: Essays in Honour of Else M. Barth, Amsterdam: Rodopi. [CF]

KREIDER, A. J., 2007, "Informal fallacies as inferences to the best explanation," ISSA 6: 823-26. [GF-N]

VAN LAAR, JAN AlBert, 2010, "Ambiguity in argument," Argument and Computation, 1: 125-46. [AM-A] [AM-E]

LANGE, MARC, 2002, "Baseball, pessimistic inductions and the turnover fallacy," Analysis, 62: 281-85. [SF]

LAVINE, T. Z., 1962, "Reflections on the genetic fallacy," Social Research, 29: 321-36. [FG]

LEDDY, THOMAS, 1986, "Is there a fallacy of small sample?" Informal Logic, 8: 53-6. [FB]

LEFF, Michael, 2007, “Ad hominem argument in the Bush/Kerry presidential debates.” ISSA 6: 859-65. [AH-N] 
456 A Searchable Bibliography of Fallacies

LEIBOWITZ, URI D., 2016, "Moral deliberation and ad hominem fallacies," J. of Moral Philosophy, 13: 507-29. [AH-N]

LEVI, DoN S., 1994, "Begging what is at issue in the argument," Argumentation, 8: 265-82. [BQ]

__ 1999, "The fallacy of treating the ad baculum as a fallacy," Informal Logic, 19: 145-59. [AB]

LEWIŃSKI, MARCIN, 2011, "Towards a critique-friendly approach to the straw man fallacy evaluation," Argumentation, 25: 469-97. [IE]

_, 2014, "Argumentative polylogues: beyond dialectical understanding of fallacies," Studies in Logic, Grammar, and Rhetoric, 38: 193-218. [GF-D]

LEWIS, Frank A., 2009, "Parmenides' modal fallacy," Phronesis, $54: 1-8 .[\mathrm{ScF}]$

LEWIS, PETER J., 2001, "Why the pessimistic induction is a fallacy," Synthese, 129: 371-80. [ScF]

LONGAKER, MARK GARRETT, 2014, "John Locke on inference and fallacy: A re-appraisal," Informal Logic, 34: 364-92. [GF-N]

LUMER, CHRISTOPH, 2000, "Reductionism in fallacy theory," Argumentation, 14: 405-23. [GF-E]

Macagno, Fabrizio and Douglas Walton, 2007, "The fallaciousness of threats: characterand ad baculum," Argumentation, 21: 63-81. [AB]

_, 2012, "Character attacks as complex strategies of legal argumentation," International J. of Law, Language \& Discourse, 2: 59-117. [AH-A]

Macintosh, J. J., 1991, "Theological question-begging," Dialogue, 30: 531-47. [BQ]

MACKENZIE, JIM, 1979, "Question begging in non-cumulative systems," J. of Philosophical Logic, 8: 117-33. [BQ]

, 1984, "Begging the question in dialogue," Australasian J. of Philosophy, 62: 174-81. [BQ]

, 1984, "Confirmation of a conjecture of Peter of Spain concerning begging the question," J. of Philosophical Logic, 8: 117-33. [BQ] [HIS]

_ , 1988, "Distinguo: The response to equivocation," Argumentation, 2: 465-82. [AM-E]

_, 1994, "Contexts of begging the question," Argumentation, 8: 227-40. [BQ]

Mackie, John L., 1967, “Fallacies,” In Encyclopedia of Philosophy, 3: 169-79. [GF-N]

(C) Hans V. Hansen \& Cameron Fioret. Infomal Logic, Vol. 36, No. 4 (2016), pp. 432-472. 
MAIER, ROBERT, 1987, "Cognitive development and fallacies," in ISSA $1 B:$ 75-82. [GF-P]

MARKS, JoEL, 1988, "When is a fallacy not a fallacy?" Metaphilosophy, 19: 307-12. [GF-N]

MARSHALL, ERNEST, 1987, "Formalism, fallacies, and the teaching of informal logic," In ISSA 1B: 386-93. [GF-E] [FF] [GF-T]

MASSEY, GERALD, 1975, "Are there any good arguments that bad arguments are bad?" Philosophy in Context, 4: 61-77. [GF-E]

, 1975, "In defense of the asymmetry," Philosophy in Context (Supplementary), 4: 44-55. [GF-E]

_, 1995, "The fallacy behind fallacies," Midwest Studies in Philosophy 6: 489-500. Also in Hansen and Pinto 1995, 159-71. [GF-E]

Maxwell, E. A., 1959, Fallacies in Mathematics, Cambridge: Cambridge University Press. [FM]

MAYER, JÖRG, 2002, "The fallacy of composition: a review of literature," The World Economy, 25: 875-94. [CM]

MCCANDLESS, DAVID, 2012, "Rhetological fallacies: errors and manipulation of rhetoric and logical thinking," Information is Beautiful (3 Feb. 2014) <http:// www.informationisbeautiful .net/visualizations/rhetological-fallacies/>. [GF-R]

MCPECK, JOHN, 1991, "What is learned in informal logic courses?" Teaching Philosophy, 14: 25-34, [Criticism of the purported value of teaching the fallacies as part of critical thinking]. [GF-T]

Michael, Michael, 2010, "Critical engagement: reflections on the ad hominem fallacy and on critical thinking education," WSEAS Transactions on Biology and Biomedicine, 3: 179-89. [AH-N] [GF-T]

Michalos, Alex C., 1976, Improving Your Reasoning (2nd ed.), Englewood Cliffs: Prentice-Hall, [1st ed. 1970]. [BT]

MikKOnEN, JuKKA, 2009, "The realistic fallacy, or: the conception of literary narrative fiction in analytic aesthetics," Studia Philosophica Estonica, 2: 1-18. [XX]

Minot, Walter S., 1981, "A rhetorical view of fallacies: $\mathrm{Ad}$ hominem and ad populum," Rhetorical Society Q., 11: 22235. [AH-N] [AM-A]

Missimer, CONNIE, 1998, "Do the fallacies you favour retard the growth of knowledge?" OSSA 2, [GF-N] 
MizRAHI, MotI, 2010, “Take my advice-I am not following it: ad hominem arguments as legitimate rebuttals to appeals to authority," Informal Logic, 30: 435-56. [AA]

MOHAMMED, DimA, 2009, "Ad hominem as a derailment of confrontational strategic manoevring," OSSA 8. [AH-N]

MoretTi, LuCA, 2008, "Brogaard and Salerno on antirealism and the conditional fallacy," Philosophical Studies, 140: 22946. $[\mathrm{FF}]$

MORO, Rodrigo, 2009, "On the nature of the conjunction fallacy,” Synthese, 171: 1-24. [FK]

Mosteller, Timothy, 2016, "Phronesis and fallacies," ECA 1 vol. 2: 719-32.

Nelson, Leonard, 2016, A Theory of Philosophical Fallacies, trans. by Fernando Leal and David Carus, Cham, Switzerland: Springer. [AM-E] [FD]

NuCHELMANS, GABRIEL, 1993, "On the fourfold root of argumentum ad hominem," in Krabbe et al., 1993, 37-47. [AH-N]

OAKSFORD, MiKe, and Nick CHATER, 2011, "The 'Is-Ought Fallacy' Fallacy," Behavioral and Brain Sciences, 34: 262-63. [FN]

OLIVER, JAMES WILLARD, 1967, "Formal fallacies and other invalid arguments," Mind, 76: 463-78, [Anticipates Massey's papers on the asymmetry thesis]. [GF-E]

Oswald, S., and HART C., 2013, "Trust based on bias: cognitive constraints on source related fallacies," OSSA 10. [AA]

Otteson, JAmes R., 2010, "Adam Smith and the great mind fallacy," Social Philosophy and Policy, 27: 276-304. [XX]

PAGLIERI, FABIO, 2016, "Don't worry, be gappy! On the unproblematic gappiness offallacies," OSSA 11. [GF-N] [GF-E]

PALMER, HumphreY, 1981, "Do circular arguments beg the question?” Philosophy, 56: 387-94. [BQ]

PAPRZYCKA, KATARZYNA, 2014, "On a neg-raising fallacy in determining enthymematicity: I she did not believe or want...," Metaphilosophy, 45: 96-119. [XX]

PARKER, RICHARD A., 1984, "Tu quoque arguments: A rhetorical perspective," J. of the American Forensic Association, 20: 123-32. [AH-Q]

PASHMAN, Jon, 1970, "Is the genetic fallacy a fallacy?" Southern J. of Philosophy, 8: 57-62. [FG] , 1971, "Reply to Mr. Kleiman,” Southern J. of Philosophy, 9: 93-94, [Reply to Kleiman 1970]. [FG] 
PAtTerson, Steve, 2011, "A fallacies concept map," RAIL Blog (23 Feb. 2011) <http://railct.com/2011/02/23/philo sorapters-visual-taxonomy-of-logical-fallacies/>. [GF C]

_, 2013, "Dishonesty and fallacious arguing," RAIL Blog (7 Mar. 2013) <http://railct.com/2013/03/07/dishonesty-andfallacious-arguing/>. [GF-N]

Pederson, N. J. L. L., and Jesper Kallestrup, "The epistemology of absence-based inference," Synthese, 190: 257393. [AI]

Pilgram, Roosmaryn, and Leah E. Polcar, 2007, "Questioning the fallacy of many questions," ISSA 6:1059-63. [FQ]

PINEAU, ANDREW, 2013, "The abuses of argument: understanding fallacies on Toulmin's layout of argument," Informal Logic, 33: 531-46. [GF-E]

PINTO, Robert C., 1995, "Post hoc ergo propter hoc," In Hansen and Pinto 1995, 302-14. [PP]

PirIe, Madsen, 1965, The Book of Fallacy: A Training Manual for Intellectual Subversives, LonDON: Routledge and Kegan Paul. [BT]

Powers, LaWrence H., 1995, "Equivocation," In Hansen and Pinto 1995, 287-301. [AM-E]

_, 1995, "The one fallacy theory," Informal Logic, 17: 303-14. [GF] [AM-E]

, 1998, “Ad hominem arguments," in OSSA 2. [AH-A] [AHC]

, 1999, "Dividing by zero and other mathematical fallacies," ISSA 4: 655-7. [FM]

REMLAND, MARTIN, 1982, "The implicit ad hominem fallacy: nonverbal displays of status in argumentative discourse," $J$. of the American Forensic Association, 19: 79-86. [AH-N]

RESCHER, NiCHOLAS, 1987, "How serious a fallacy is inconsistency?" Argumentation, 1: 303-16. [GF-E]

RIBEIRO, BRIAN, 2008, "How often do we (philosophy professors) commit the straw man fallacy?" Teaching Philosophy, 31: 27-38. [IE] [GF-T]

RIEPE, DALE, 1966, "Some reconsiderations of the argumentum ad hominem," Darshana International, 6: 44-7. [AH-N]

RitolA, JUHO, 2003, “On reasonable question-begging arguments?" ISSA 5: 913-17. [BQ]

_, 2009, "Two accounts of begging the question," OSSA 8. [BQ] 
460 A Searchable Bibliography of Fallacies

ROBINSON, RichaRD, 1941, “Ambiguity," Mind, 50: 140-55. [AM-E] [AMBIG.]

_, 1942, "Plato's consciousness of fallacy," Mind, 51: 94-114. [GF-N] [HIS]

_., 1971a, “Arguing from ignorance," Philosophical Q., 21: 97 108. [AI]

_, 1971b, "Begging the question, 1971," Analysis, 31: 113-17. [BQ]

_., 1981, "Begging the question, 1981," Analysis, 41: 65. [BQ]

RoHATYN, DENNIS, 1987, "When is a fallacy a fallacy?" in ISSA 1B: 45-55. [GF-N]

Rowe, William L., 1962, "The fallacy of composition," Mind, 71: 87-92. [CM]

RuDANKo, JUHANI, 2009, "Reinstating and defining ad socordiam as an informal fallacy: A case study from a political debate in the early American republic," OSSA 8. [XX] [HIS]

_, "Identifying a new type of fallacy in discourse," OSSA 10. $[\mathrm{XX}]$

SAHLAne, A., 2012, "Argumentation and fallacy in the justification of the 2003 War on Iraq," Argumentation 26: 459-88. [AH-A] [AH-C] [AB] [AC]

SANFORD, DAVID, 1972, "Begging the question," Analysis, 32: 197-9. [BQ]

, 1977, "The fallacy of begging the question: A reply to Barker," Dialogue, 16: 485-98, [Reply to Barker 1976]. [BQ]

_, 1981, "Superfluous information, epistemic conditions of inference, and begging the question," Metaphilosophy, 12: 14558. [BQ]

Schedler, GeORGE, 1988, "The argument from ignorance," International Logic Review, 11: 66-71. [AI]

SCHELlEns, P. I., 1991, Ad verecundiam and ad hominem arguments as acceptable fallacies, in ISSA 2: 384-90. [AA] [AH$\mathrm{N}]$

SCHLECHT, LUDWIG F., 1991, "Classifying fallacies logically," Teaching Philosophy, 14: 53-64. [GF-C]

SCHMidT, Michael F., 1986, "Fallacies: A bibliography in progress," Informal Logic, 8: 105-11. [OB] , 1986, "On classification of fallacies," Informal Logic, 8: 5766. [GF-C]

, 1991, "Inconsistency, falsity, incompleteness, begging the question and missing the point," in ISSA 2A: 403-10. [BQ]

(C) Hans V. Hansen \& Cameron Fioret. Infomal Logic, Vol. 36, No. 4 (2016), pp. 432-472. 
Schmidt, Michael F. and Hans V. Hansen, 1998, "Current bibliography," in C.L. Hamblin, Fallacies, Newport News, Vale Press, 327-49. [OB]

SCHUlze, JAN HenNING, 2015, “Think twice: Fallacies and dualprocess accounts of reasoning," ISSA 8: 1313-19. [GF-P]

SCRIVEN, MichaEL, 1987, "Fallacies of statistical substitution," Argumentation, 1: 333-49. [SF]

SECOR, MARIE, 1987, "How common are fallacies?" Informal Logic, 9: 41-8, [Response to Jason 1986]. [GF-E]

_, 1999, "Augustus de Morgan on fallacy: pettyfoggers and controversialists," OSSA 3. [GF-E] [HIS]

_, 2003, "Reconsidering contentious argument: Augustus DeMorgan on fallacy," Argumentation, 17: 131-43. [GF-E] [HIS]

Sgaravatti, Daniele, 2013, "Petitio principii: A bad form of reasoning," Mind, 122: 749-79. [BQ]

SHAFFER, MichAel J., 2007, "The ad verecundiam fallacy and appeals to expert testimony," in ISSA 6: 1265-9. [AA]

SHIER, DAVID, and J. LeE TILsOn, 2006, "The temporal stage fallacy: A novel statistical fallacy in the medical literature," Medicine, Health Care and Philosophy, 9: 243-7. [SF]

SHOGENJ, TOMOJI, 2012, "The degree of epistemic justification and the conjunction fallacy," Synthese, 184: 29-48. [FK]

SHUPBACH, JONAH N., 2012, "Is the conjunction fallacy tied to probabilistic confirmation?" Synthese, 184: 13-27. [FK]

Shuzue, Zhang, 2003, "Argumentum ad hominem in a crosscultural perspective," ISSA 5: 953-7.

SIEGEL, HARVEY, and JOHN BIRO, 1997, "Epistemic normativity, argumentation, and fallacies," Argumentation, 11: 277-92. [GF-E]

SORENSON, RoY A., 1989, "Slipping off the slippery slope: A reply to Professor Jacquette," Philosophy \& Rhetoric, 22: 195-202. [SS]

, 1989, "P, therefore P, without circularity," J. of Philosophy, 88: 245-66. [BQ]

_, 2016, "Fugu for logicians," Philosophy and Phenomenological Research, 92: 131-44. [GF-E]

SOUdER, LAWrence, and Furrah QuRESHI, 2012, “Ad hominem arguments in the service of boundary work among climate scientists," J. of Science Communication, 11:1-11. [AH

$\mathrm{N}]$ 
462 A Searchable Bibliography of Fallacies

SPARKES, A. W., 1966, "Begging the question," J. of the History of Ideas, 27: 462-3. [BQ]

Sprague, Rosamund Kent, 1962, Plato's use of fallacy: A study of the Euthydemus and some other dialogues, London: Routledge and Kegan Paul. [GF-D] [HIS]

StARK, Herman E., 2000, "The Lord Scroop fallacy," Informal Logic, 20: 245-59. [XX]

Stone, MARK A., 2012, "Denying the antecedent: its effective use in argumentation," Informal Logic, 32: 327-56. [FF]

Strenski, IVAN, 2004, Ad hominem reviews and rejoinders: Their uses and abuses, Method and Theory in the Study of Religion, 16: 367-85.

SUBER, PETER, 1994, "Question-begging under a nonfoundational model of argument," Argumentation, 8: 241-50. [BQ]

TANNER, JULIA, 2006, “The naturalistic fallacy," Richmond J. of Philosophy, 13: 1-6. [FN]

TAYLOR, RICHARD, 1995, "The utilitarian fallacy," Argumentation, 9: 531-41. [XX]

Tentori, Katya, and Vincenzo Crupi, 2012, "How the conjunction fallacy is tied to probabilistic confirmation: some remarks on Schupbach (2009)," Synthese, 184: 3-12. [FK]

TINDAle, Christopher W., 1996, "Fallacies in transition: an assessment of the pragma-dialectical perspective," Informal Logic, 18: 17-33. [GF-D]

_, 2007a, "On fallacy” in Hansen and Pinto 2007, 155-70.

_, 2007b, Fallacies and Argument Appraisal, Cambridge: Cambridge University Press. [GF-N] [BT]

Tomic, TAEDA, 2013, "False dilemma: A systematic exposition," Argumentation, 27: 347-68. [FD]

TRICK, LANA M. and Christopher J. R. RONEY, 2011, "Sympathetic magic and perceptions of randomness: the hot hand versus the gambler's fallacy," Thinking and Reasoning, 15: 197-210. [FR]

Urbieta, Leire, and Begona CARrascal, 2007, "Circular arguments analysis," ISSA 6: 1395-1400. [BQ]

URMSON, J. O., 1995, “A fallacy of Aristotle's about ends," Argumentation, 9: 523-30. [HIS]

VAte, Dwight VAn De, JR., 1975a, "The appeal to force," Philosophy \& Rhetoric, 8: 43-60. [AB]

_, 1975b, "Reasoning and threatening: A reply to Yoos," Philosophy \& Rhetoric, 8: 177-9. [AB] 
Veber, Michael, 2012, “'People who argue ad hominem are jerks' and other self-fulfilling fallacies," Argumentation, 26: 201-12. [GF-N]

VAn Veuren, PIETER, 1994, “'Ideological' fallacies,” Koers: Bulletin for Christian Scholarship, 59: 37-51. [GF]

WAGEMANS, JEAN, 2003, "Conceptualizing fallacies: The Informal Logic and Pragma-Dialectical approaches to the argumentum ad ignorantiam," ISSA 5: 1049-51. [GF-D]

WALsCHOTs, Michael, 2011, "Ernest Sosa and virtuously begging the question," OSSA 9. [BQ]

Walton, Douglas N., 1977, "Mill and De Morgan on whether the syllogism is a petitio," International Logic Review, 8: 5768. [BQ] [HIS]

_, 1980, "Petitio principii and argument analysis," In Blair and Johnson 1980, 41-54. [BQ]

_, 1980, "Why is the ad populum a fallacy?" Philosophy \& Rhetoric, 13: 264-78. Also in Woods and Walton 1989, 20920. [AM-A]

, 1981, "The fallacy of many questions," Logique et Analyse, 95-96: 291-313. Also in Woods and Walton 1989, 233-51. [FQ]

_, 1982, Topical Relevance in Argumentation, Amsterdam: John Benjamins. [GF-N]

_, 1984, "Logical Dialogue-Games and Fallacies, Lanham: University Press of America. [GF-D]

_, 1985, “Are circular arguments necessarily vicious?” American Philosophical Q., 22: 263-74. [BQ]

_, 1985, Arguer's Position: A Pragmatic Study of 'Ad Hominem' Attack, Criticism, Refutation and Fallacy, Westport: Greenwood. [AH-N]

_, 1987, "The ad hominem argument as an informal fallacy," Argumentation, 1: 317-31.[AH-N]

_, 1987, Informal Fallacies: Towards a Theory of Argument Criticisms, Amsterdam: John Benjamins. [GF-N]

_ , 1987, "What is a fallacy?" In Van Eemeren, Grootendorst, et al., 1987a, 323-30. [GF-N]

_, 1988, "Question-asking fallacies.," in Questions and Questioning, Meyer, M., (ed.), 195-221, Berlin: De Gruyter. [FQ]

_ , 1989, "Reasoned use of expertise in argumentation," Argumentation, 3: 59-73. [AA] 
464 A Searchable Bibliography of Fallacies

, 1990, "Ignoring qualifications (secundum quid) as a subfallacy of hasty generalization," Logique et Analyse, 33: 113-54. [SQ]

_, 1991a, Begging the Question: Circular Reasoning as a Tactic of Argumentation, New York: Greenwood. [BQ]

_, 1991b, "Bias, critical doubt, and fallacies," Argumentation and Advocacy, 28: 1-22. [GFD]

_, 1991c, "Critical faults and fallacies of questioning," J. of Pragmatics, 15: 337-66. [FQ] [BQ]

_, 1991, "Hamblin on the standard treatment of fallacies," Philosophy \& Rhetoric, 24: 353-61, [Reply to R.H. Johnson, 1990]. [GF-N]

, 1992, "Commitment, types of dialogue, and fallacies," Informal Logic, 14: 93-103. [GFD]

, 1992, "Nonfallacious arguments from ignorance," American Philosophical Q., 29: 381-7. [AI]

, 1992, Slippery Slope Arguments, Oxford: Oxford University Press. Re-issued in 1999 by Newport News: Vale Press. [SS]

_, 1992, "Types of dialogue, dialectical shifts and fallacies," in ISSA 2: 133-47. [GF-D]

_, 1992, "Which of the fallacies are fallacies of relevance?" Argumentation, 6: 237-50. [GF- C]

_, 1993, "Alethic, epistemic, and dialectical models of argument," Philosophy and Rhetoric, 26: 302-10. [GF-N]

_, 1994, "Begging the question as a pragmatic fallacy," Synthese, 100: 95-131. [BQ]

_, 1995, A Pragmatic Theory of Fallacy, Tuscaloosa: University of Alabama Press. [GF-D]

_, 1995, "Ad hominem: From Johnstone to Locke to Aristotle," in ISSA 3: 395-408. [AH-N]

_, 1995, "Appeal to pity: a case study of the argumentum ad misericordiam," Argumentation, 9: 769-84. [MIS]

_, 1995, "The essential ingredients of the fallacy of begging the question," in Hansen and Pinto, 1995, 229-39. [BQ]

, 1996, Arguments from Ignorance, University Park: The Pennsylvania State University Press. [AI]

_, 1996, Fallacies Arising from Ambiguity, Dordrecht: Kluwer. [AM-E]

_, 1996, "Plausible deniability and the evasion of burden of proof," Argumentation, 10: 47-58. [SB] 
, 1996, "Practical reasoning and the structure of fear appeal arguments', Philosophy and Rhetoric, 29: 301-13. [AB]

_, 1996, "The argument of the beard," Informal Logic, 18: 235 59. [SS]

, 1997, Appeal to Expert Opinion: Arguments from Authority, University Park: Pennsylvania State University Press. [AA]

_., 1997, Appeal to Pity: Argumentum ad Misericordiam, Albany: State University of New York Press. [MIS]

_., 1997, "Judging how heavily a question is loaded: a pragmatic method', Inquiry: Critical Thinking Across the Disciplines, 17: 53-71. [FQ]

, 1998, Ad Hominem Arguments, Tuscaloosa: University of Alabama Press. [AH-N]

_, 1999, Appeal to Popular Opinion, University Park: The Pennsylvania State University Press. [AM-A]

_, 1999, "Ethotic arguments and fallacies: The credibility function in multi-agent dialogue systems," Pragmatics and Cognition, 7: 177-203. [AH-N]

_, 1999, "Historical origins of argumentum ad consequentiam," Argumentation, 13: 251-64. [AC]

, 1999, "Informal fallacy," The Cambridge Dictionary of Philosophy, Cambridge: Cambridge University Press, 431-5. [GF-N]

_, 1999, "Profiles of dialogue for evaluating arguments from ignorance," Argumentation, 13: 53-71. [AI]

_, 1999, "Rethinking the fallacy of hasty generalization," Argumentation, 13: 161-82. [HG]

_, 1999, "The appeal to ignorance, or argumentum ad ignorantiam', Argumentation, 13: 367-77. [AI]

, 1999, "The fallacy of many questions: on the notions of complexity, loadedness and unfair entrapment in interrogative theory," Argumentation, 13: 379-83. [FQ]

, 2000, "Case study of the use of the circumstantial ad hominem in political argumentation," Philosophy \& Rhetoric, 33: 101-15. [AH-N]

_, 2000, "Evaluating appeals to popular opinion," Inquiry: Critical Thinking Across the Disciplines, 20: 33-45. [AM-A]

_, 2000, "New dialectical rules for ambiguity," Informal Logic, 20: 261-74. [AM-E]

_, 2000, Scare Tactics: Arguments that Appeal to Fear and Threats, Dordrecht: Kluwer Academic Publishers. [AB] 
_, 2000, "Use of ad hominem argument in political discourse: the Battalino case from the impeachment trial of President Clinton," Argumentation and Advocacy, 36: 179-95. [AH-N]

_, 2001, "Searching for the roots of the circumstantial ad hominem," Argumentation, 15: 207-21. [AH-N]

_, 2002, "The sunk costs fallacy or argument from waste," Argumentation, 16: 473-503.[XX]

_, 2004, "Argumentation schemes and historical origins of the circumstantial ad hominem argument," Argumentation, 18: 359-68. [AH-N]

, 2004, "Classification of fallacies of relevance," Informal Logic, 24: 71-103. [GF-C]

_, 2004, Relevance in Argumentation, Mahwah, New Jersey: Lawrence Erlbaum Associates. [GF-N] , 2005, "Begging the question in arguments based on testimony," Argumentation, 19: 85-113. [BQ]

, 2006, "Epistemic and dialectical models of begging the question," Synthese, 152: 237-84. [BQ]

_, 2006, "Poisoning the well," Argumentation, 20: 273-307. [AH-C]

, 2008, "Bias, critical doubt and fallacies," Aguayo, Angela J. and Timothy R. Steffensmeier (eds.), Readings on Argumentation, State College: Strata Publishing, 168-90. (Reprint of Walton 1991b.) [GF-N]

, 2010, "Formalization of the ad hominem argumentation scheme," J. of Applied Logic 8: 1-21. [AH-N]

_, 2010, "Why fallacies appear to be better arguments than they are," Informal Logic, 30.2: 159-84. [GF-N]

_, 2011, "Defeasible reasoning and informal fallacies," Synthese, 178: 377-407. [GF-N]

, 2013, Methods of Argumentation, Cambridge: Cambridge University Press. (Ch. 8] [GFN]

_, 2014, "A dialectical analysis of the ad baculum fallacy," Informal Logic, 34: 276-310. [AB]

_, 2014, “On a razor's edge: evaluating arguments from expert opinion," Argument and Computation, 5: 139-59. [AA]

_,2014, "Speech acts and indirect threats in ad baculum arguments: a reply to Budzynska and Witek," Argumentation, 28: 317-24. [AB]

_ 2015, "The basic slippery slope argument," Informal Logic, 35: 273-311. [SS] 
Walton, Douglas, and L. M. BAtten, 1984, "Games, graphs, and circular arguments," Logique et Analyse, 27: 133-64. [BQ]

Walton, Douglas, and Thomas F. Gordon, 2009, "Jumping to a conclusion: fallacies and standards of proof," Informal Logic, 29: 215-43. [GF-N]

Walton, Douglas, and Marcin Koszowy, 2015, "Two kinds of arguments from authority in the ad vercundiam fallacy," ISSA 8: 1483-92. [AA]

Walton, Douglas N., and Erik C.W. KrabBe, 1995, Commitment in Dialogue: Basic Conceptsof Interpersonal Reasoning, Albany: State University of New York Press. [Sections 3.3 and 3.4 discuss dialectical shifts and fallacies]. [GFD]

Walton, Douglas, and Fabrizio Macagno, 2007, "The fallaciousness of threats: Character and ad baculum," Argumentation, 21: 63-81. [AB]

WARD, ANDREW C., 2010, "The value of genetic fallacies," Informal Logic, 30: 1-33. [FG]

Welzel, AndreA, and Christopher W. Tindale, 2007, "Fallacies as violations of rationality norms: an interdisciplinary approach," [GF-N] [AC] ISSA 6: 1483-9.

WeISS, STEPHEN E., 1976, "The sorites fallacy: what difference does a peanut make?" Synthese, 33: 253-72. [SS]

WERTZ, S. K., 1985, "When affirming the consequent is valid," International Logic Review, 16: 17-8. [AC]

WhITE, DAVID, 1985. "Slippery slope arguments," Metaphilosophy, 16: 206-13. [SS]

Willard, Charles ArThur, 1995, "Failures of relevance: a rhetorical view," in Hansen and Pinto 1995, 145-58. [AM-A] [GF-R]

WILliams, BERNARD, 1985, "Which slopes are slippery?" Lockwood, Michael (ed.), Moral Dilemmas in Modern Medicine, Oxford: Oxford University Press, 126-37. [SS]

Williams, M. E., 1967-68, "Begging the question?" Dialogue, 6: 567-70. [BQ]

WiLson, Kent, 1988, "Circular arguments," Metaphilosophy, 19: 38-52. [BQ]

, 1993, "Comment on Peter of Spain, Jim Mackenzie, and begging the question," J. of Philosophical Logic, 22: 323-31. [BQ] [HIS] 
468 A Searchable Bibliography of Fallacies

_, 1999, "Formal fallacy," The Cambridge Dictionary of Philosophy, Cambridge: Cambridge University Press. 316-7. $[\mathrm{FF}]$

WOHLRAPp, HARALD, 1991, “Argumentum ad baculum and ideal speech situation," in ISSA 2: 397-402. [AB]

Wolfe, Christopher R., 2007, "Adaptive redundancy, denominator neglect, and the base-rate fallacy," Behavioral and Brain Sciences, 30: 286-7. [BR]

Wolfe, Julian, 1986, "Inconsistency: a fallacy?," Informal Logic, 8: 151-2. [XX]

Wong, WAI-Hung, and ZANJA YudELL, 2013, "How fallacious is the consequence fallacy?" Philosophical Studies, 165: 2217. $[\mathrm{AC}]$

Woods, JoHn, 1980, "What is informal logic?" in Blair and Johnson 1980, 57-68. Also in Woods and Walton 1989, 22132 , [Investigates the formal approach to some fallacies, especially composition and division]. [GF-E] [FF]

, 1987, "Ad baculum, self-interest and Pascal's wager," in $I S$ SA 1: 343-9. [AB]

, 1988, "Buttercups, GNP's and quarks: are fallacies theoretical entities?" Informal Logic, 10: 67-76. [GF-N]

, 1991, "Pragma-dialectics: a radical departure in fallacy theory," Communication and Cognition, 24: 43-54. [GF-D]

, 1992, "Who cares about the fallacies?" in ISSA 2A: 23-48. [GF-N]

, 1993, "Secundum quid as a research programme," in Krabbe et al., 1993, 27-36. [SQ]

, 1994, "Is the theoretical unity of the fallacies possible?" Informal Logic, 16: 77-85. [GFN]

_, 1995, "Appeal to force," in Hansen and Pinto 1995, 240-50. [AB]

, 1995, "Fearful symmetry," in Hansen and Pinto, 1995, 18198. [GF-N]

, 1997, "Review of Douglas Walton (1991a)," Dialogue: 43540. [BQ]

, 1998, "Argumentum ad baculum," Argumentation, 12: 493504. $[\mathrm{AB}]$

_, 2000, "Slippery slopes and collapsing taboos," Argumentation, 4: 107-134. [SS]

_, 2005, "Ad hominem argument," The Oxford Companion to Philosophy, Oxford: Oxford University Press, 7. [AH-N] 
_, 2005, "Genetic fallacy," in The Oxford Companion to Philosophy, New Edition, Oxford: Oxford University Press, 331. [FG]

_, 2005, "Many questions fallacy," in The Oxford Companion to Philosophy, New Edition, Oxford: Oxford University Press, 553. [FQ]

, 2007, "Lightening up on the ad hominem," Informal Logic, 27: 109-34. [AH-N]

_, 2008, "Begging the question is not a fallacy," in Cédric Dégremont, Laurent Keiff, Helge Rükert (eds.), Dialogues, Logics and Other Strange Things: Essays in Honour of Shahid Rahman, London: College Publications, 523-44. [BQ]

_, 2009, "Knowledge by telling: reflections on the ad verecundiam," OSSA 8. [AA]

_, 2010, The Death of Argument: Fallacies in Agent-Based Reasoning, Amsterdam: Springer. [GF]

_ , 2012, "A history of fallacies in western logic", in Dov M. Gabbay, Francis Jeffry Pelletier and John Woods (eds.), Logic: A History of its Central Concepts, Amsterdam: NorthHolland, 513-610. [GF-N]

_, 2013, Errors of Reasoning: Naturalizing the Logic of Inference, Studies in Logic London: College Publications London. [GF-N]

Woods, JoHn and Dov GABBAY, 1999, Ad baculum is not a fallacy," in ISSA 4: 221-4. [AB]

_, 2009, "Fallacies as cognitive virtues," in Ondrej Majer, Ahti-Veikko Pietarinen, and Tero Tudenheimo (eds.), Games: Unifying Language, Logic and Language, Amsterdam:Springer, 57-98. [GF-V]

Woods, John and Hans V. Hansen, 1997, "Hintikka on Aristotle's fallacies," Synthese, 113: 217-239. [GF-D] [HIS]

_, (2001) "The subtleties of Aristotle on non-cause," Logique et Analyse 176: 395-415. [XX] [HIS]

Woods, John, Andrew Irvine, and Douglas Walton, 2003, Argument, Critical Thinking, Logic, and the Fallacies, Toronto: Pearson Education Canada. [BT]

Woods, John, and Douglas N. WALton, 1972, "On fallacies," J. of Critical Analysis 4:103-11. Also in Woods and Walton 1989, 1-10. [GF-N]

_, 1974, "Argumentum ad verecundiam," Philosophy \& Rhetoric, 7: 135-53. Also in Woods and Walton 1989, 11-28. [AA] 
470 A Searchable Bibliography of Fallacies

, 1975, "Is the syllogism a petitio principii," The Mill News Letter, 10: 13-5. [BQ] [HIS]

_, 1975, "Petitio principii," Synthese, 31: 107-27. Also in Woods and Walton 1989, 29-45. [BQ]

_, 1976a, "Ad baculum," Grazer Philosophische Studien, 2: 133-40. Also in Woods and Walton 1989, 47-53. [AB]

_, 1976b, "Fallaciousness without invalidity?" Philosophy \&Rhetoric, 9: 52-4. [GF-N]

_, 1977a, “Ad hominem," Philosophical Forum, 8: 1-20. Also in Woods and Walton 1989, 55-73. [AH-N]

_, 1977b, “Ad hominem, contra Gerber," The Personalist, 58: 141-44. Also in Woods and Walton 1989, 87-91. [AH-N]

_, 1977c, “Composition and division," Studia Logica, 36: 381406. Also in Woods and Walton 1989, 93-119. [CM] [DI]

_, 1977d, "Petitio and relevant many-premissed arguments," Logique et Analyse, 20: 97-110. Also in Woods and Walton 1989, 75-85. [BQ]

, 1977e, "Post hoc, ergo propter hoc," Review of Metaphysics, 30: 569-93. Also in Woods and Walton 1989, 121-41. [PP]

, 1978a, "Arresting circles in formal dialogues," J. of Philosophical Logic, 7: 73-90. Also in Woods and Walton 1989, 143-59. [BQ]

_, 1978b, "The fallacy of ad ignorantiam," Dialectica, 32: 8799. Also in Woods and Walton 1989, 161-73. [AI]

_., 1979, "Equivocation and practical logic," Ratio, 21: 31-43. Also in Woods and Walton 1989, 195-207. [AM-E]

_, 1981, "More on fallaciousness and invalidity," Philosophy \& Rhetoric, 14: 168-72. [GFN]

_, 1982a, Argument: The Logic of the Fallacies, Toronto: McGraw-Hill Ryerson. [BT]

, 1982b, “The Petitio: Aristotle's five ways," Canadian J. of Philosophy, 12: 77-100. [BQ] [HIS]

_, 1982c, "Question-begging and cumulativeness in dialectical games," Nous, 16: 585-605. [BQ]

_, 1989, Fallacies: Selected Papers, 1972-82, Dordrecht: Foris. [GF-E]

_, 2001, Fallacies: Selected Papers 1972-1982, $2^{\text {nd }}$ Edition, London: College Publications. [GF-E] 
Wreen, Michael J., 1987a, "When no reason is good reason," in Van Eemeren, Grootendorst, et al., 1987b, 56-64, [on the ad ignorantiam]. [AI]

_, 1987b, "Yes, Virginia, there is a Santa Claus," Informal Logic 9: 31-9, [on the ad baculum]. [AB]

_ , 1988a, "Admit no force but argument," Informal Logic, 10: 89-95 (Criticizes thestandard treatment of the ad baculum fallacy). [AB]

, 1988b, "May the force be with you," Argumentation, 2: 425 40, (on the ad baculum). [AB]

_, 1989a, “A bolt of fear," Philosophy \& Rhetoric, 22: 131-40, (on the ad baculum). [AB]

, 1989b, "Light from darkness, from ignorance knowledge," Dialectica, 43: 289-314, (on the ad ignorantiam). [AI]

_, 1993, "Jump with common spirits," Metaphilosophy, 24: 6175. [POP]

_, 1994a, "What Is a fallacy?" in Johnson and Blair 1994, 93102. [GF-N]

, 1994b, "Look Ma! No Frans," Pragmatics and Cognition, 2: 285-306, (Critical assessment of the Pragma-Dialectical conception of fallacies). [GF-D]

_., 1995, “Knockdown arguments," Informal Logic, 17: 316-36. [AB]

YACKULIC, R. A., and I. W. Kelly, 1984, "The psychology of the 'Gambler's Fallacy' in probabilistic reasoning," Psychology, A Quaterly Journal of Human Behavior, 21: 55-8. [FR]

YAP, AUdREY, 2013, "Ad hominem fallacies, bias, and testimony," Argumentation, 27: 97-109. [AH-N]

_, 2015, "Ad hominem fallacies and epistemic credibility," in Argument Types and Fallacies in Legal Argumentation, Thomas Bustamante and Christian Dahlman (eds.), 19-35, Cham: Springer. [AH-N]

Yoos, GeOrge, 1975, “A critique of van de Vate's 'the appeal to force,," Philosophy and Rhetoric, 8: 172-6. [AB]

ZAGAR, IGOR, and Dima MoHAMmeD, 2011, "Fallacies: do we 'use' them or 'commit' them? or: is all our life just a collection of fallacies?" OSSA 9. [GF-N]

Zarefsky, David, 2003, "Felicity conditions for the circumstantial ad hominem: the case of Bush vs. Gore," ISSA 5: 110914. [AH-C]

ZENKER, FRANK, 2016, “The polysemy of 'fallacy' —or 'bias', for that matter," OSSA 11. [GF] 
472 A Searchable Bibliography of Fallacies

Zuckero, MATthew, 2003, "Three potential problems for Powers' one-fallacy theory," Informal Logic, 23: 285-92. [AM-E] [GF-E] 